\title{
InTRODUCTION OF AUTOMATIC MiLking AND its EfFect on Milk Production
}

\author{
MerGedus, A.; VRZEL, M.; BunEVSKI, G.; BRUS, M.; \& \\ JANZEKOVIC, $\mathrm{M}$.
}

Abstract: To evaluate the impact of a new technology in dairy production (the change in the production system and milking technique), we analysed the production and milk quality parameters data of a conventional Slovenian dairy farm. We analysed three periods: intermediate period, and the period before and after the introduction of the automatic milking systems (AMS). No significant differences were observed in the amount of milk quantity. The analysis of data showed significant differences in the following parameters: fat, protein, lactose and somatic cell count. The levels of fat, protein and lactose were significantly higher. The number of somatic cells was significantly lower after the introduction of the AMS.

Key words: milk production, cattle, robot milking, quality of milk
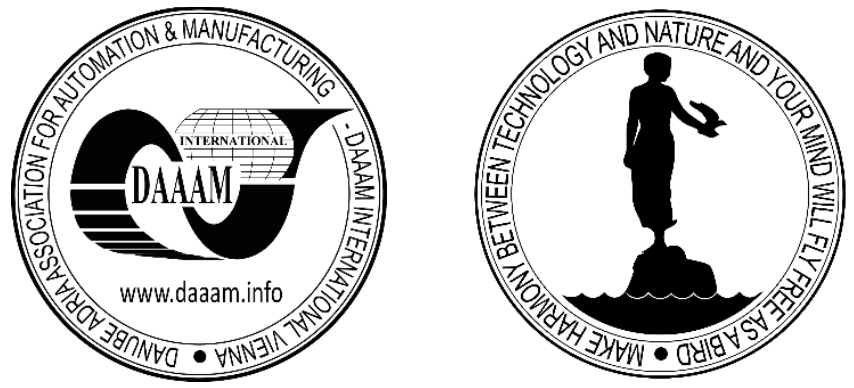

Authors' data: Dr. Sc. Mergedus, A[ndrej]*; Vrzel, M[artina]*; Univ. Prof. Dr. Sc. Bunevski G[joko]**; M. Sc. Brus, M[aksimiljan]; Assis. Prof. Dr. Sc. Janzekovic, M[arjan]*; *University of Maribor, Faculty for Agriculture and Life Sciences, Pivola 11, 2311 Hoce, Slovenia, ** Faculty of Agricultural Sciences and Food, Ss. Cyril and Methodius University in Skopje, 16-ta Makedonska brigada 3, 1000 Skopje, Macedonia, andrej.mergedus@um.si,_ martina.vrzel@gmail.com, bunevski@gmail.com,maksimiljan.brus@um.si,marjan.janzekovic@um.si

This Publication has to be referred as: Mergedus, A[ndrej]; Vrzel, M[artina]; Bunevski, G[ojko]; Brus, M[aksimiljan] \& Janzekovic, M[arjan] (2019). Introduction of Automatic Milking and its Effect on Milk Production, Chapter 09 in DAAAM International Scientific Book 2019, pp.109-122, B. Katalinic (Ed.), Published by DAAAM International, ISBN 978-3-902734-24-2, ISSN 1726-9687, Vienna, Austria DOI: $10.2507 /$ daaam.scibook.2019.09 
Mergedus, A.; Vrzel, M.; Bunevski, G.; Brus, M. \& Janzekovic, M.: Introduction of...

\section{Introduction}

Cow milking is one of the most sophisticated and a time consuming activities on dairy farms. With the increasing milk yield and increasing number of dairy cows, milking becomes even more complex. The first ideas about robotizing this work appeared in the 1970s, but first fully developed automatic milking systems (AMS) has been installed in the Netherlands in 1992 (De Koning, 2010). Studies show that AMS can replace human labor in the milking parlor and can reduce labor-hours up to $30 \%$ (Heikkila et al., 2010). AMS are mostly used in small and midsize dairy farms as a strategy to avoid or reduce the need of hiring non-family labor, and to increase productivity without increasing labor (Schewe \& Stuart, 2015).

Transition from conventional milking to automatic new milking system does not contains only a switch in milking system, but also requires a different concept of herd management. Changes are required in many farm areas from housing, feeding system and labor organization (Schewe \& Stuart, 2015). Some labor routines have to be reorganized or modified, some conventional tasks have to be cancelled and at the same time some new activities have to be introduced. There are also changes in the cow behavioural routine (Calcante and al., 2016).

The most important positive feature of this system is to allow cows to voluntarily approach the AMS to be milked individually, when they desire, and at any time of day. One AMS unit is sufficient to milk 60 - 70 cows (De Koning \& Rodenburg, 2004). Among the positive aspects of the AMS is also computerized monitoring of individual animals. AMS is monitoring different aspects of production and milk quality, and provides instant data about the performance and health status of the cow. In AMS, milking frequency can be adapted to an individual cow, taking into account her production level or stage of lactation (Calcante and al., 2016), which is another positive aspect of the system. The main negative aspect of the system is high initial investment compared to the traditional milking parlor, and AMS equipment may not last for many years (Rotz et al., 2003).

When designing a new stall and considering a conversion to robotic milking, the design of the stall must be adapted to that new equipment and management of the herd. Cow milking takes place throughout the day, which changes the feeding and resting time of the animals (Halachmi at al., 2000). A properly managed and designed free stall can have positive effect on cow comfort, which is one of the most important factors of animal well-being and positive milk production. Errors in design can contribute to mastitis, lameness, hock abrasions and other injuries, which have negative effect on production and quality of the milk (Bewley at al., 2017; Janzekovic \& Mergedus, 2016).

The main research aim of this study was to present the impact on milk quality and production after the change of the breeding system and the introduction of AMS milking to a dairy Simmnetal herd. 


\section{Materials and methods}

\subsection{Housing}

For the study, we chose a Slovenian conventional milk producing dairy farm. Until 2014, cows were placed in tie stall. At that time, the number of milked cows was 78. Milking was done with portable milking units and milk was delivered to a cooling tank over a pipeline system. The lying cubicals were short and narrow, and the floors concrete, lined with straw. Behind the cubicals there was a mud channel, which was mechanically cleaned with a mud scraper. Two cows used one water cup drinker. The tie stall ventilation was natural (windows and doors), with no ventilators. The current facility is classic closed-type free stall that allows keeping 80 dairy cows and 72 heads of young animals (Fig. 1.). The internal arrangement of the new free stall includes:

- lying pens area for dairy cows,

- dried cows area,

- maternity pen,

- individual pens for calves from 0 to 14 days old,

- two group pens for the calves up to 3 months old,

- group pens for heifers, 3-9 months old,

- group pens for heifers aged 9-15 months,

- group pens for heifers aged 15-21 months,

- group pens for heifers aged 21-27 months,

- pen for two breeding bulls,

- pens for sick animals,

- milking area with a milking robot,

- the milk tank room,

- engine room,

- office,

- sanitary facilities,

- room for storage of semen container.

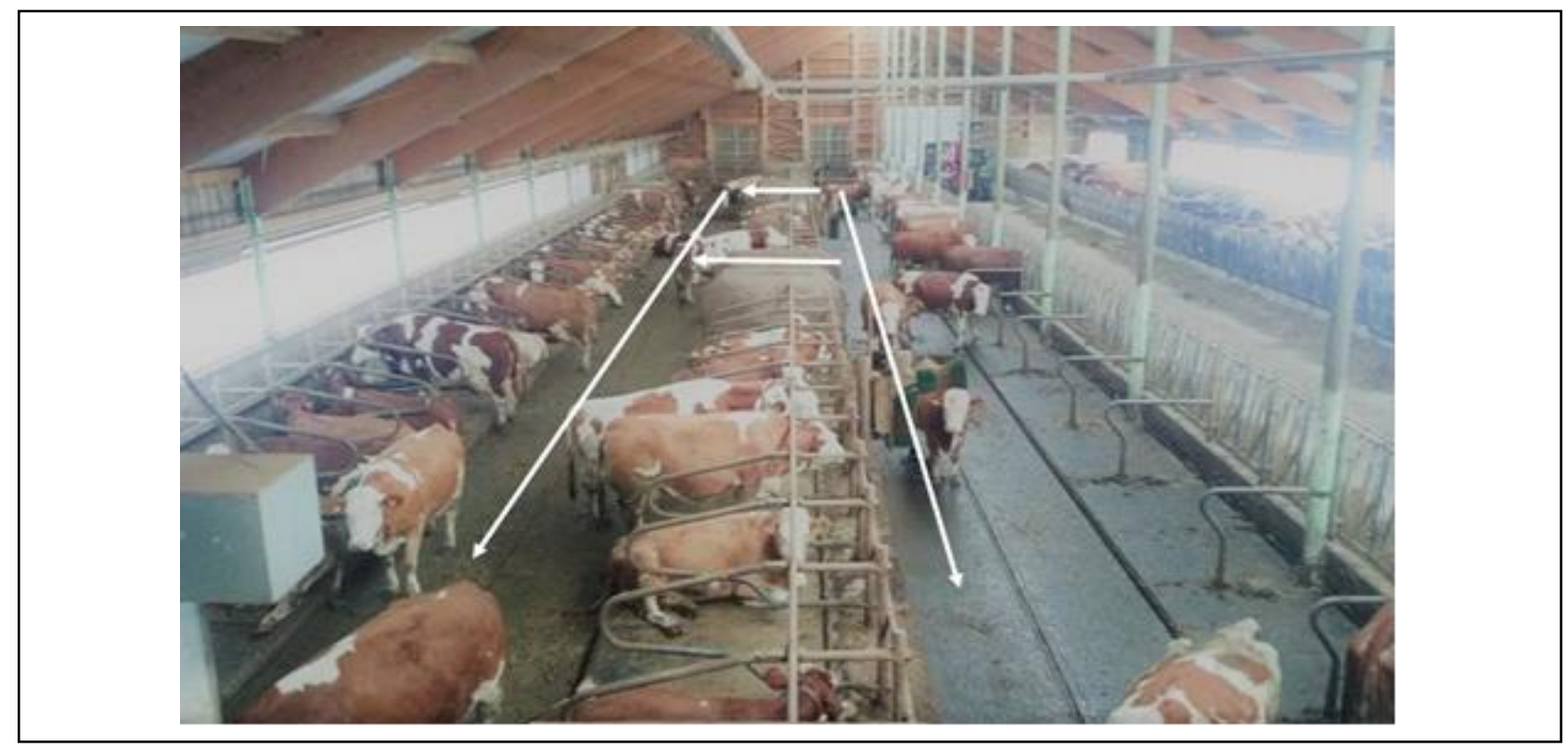

Fig. 1. Partially directed movement of cows on the farm (Vrzel, 2017). 
Mergedus, A.; Vrzel, M.; Bunevski, G.; Brus, M. \& Janzekovic, M.: Introduction of...

\subsection{Automatic milking systems}

The farm uses the milking robot Lely Astronaut A4 (Fig. 2.). Through the Lely T4C computer program, they monitor several indicators that provide information on the health and information on the milk production of each cow.

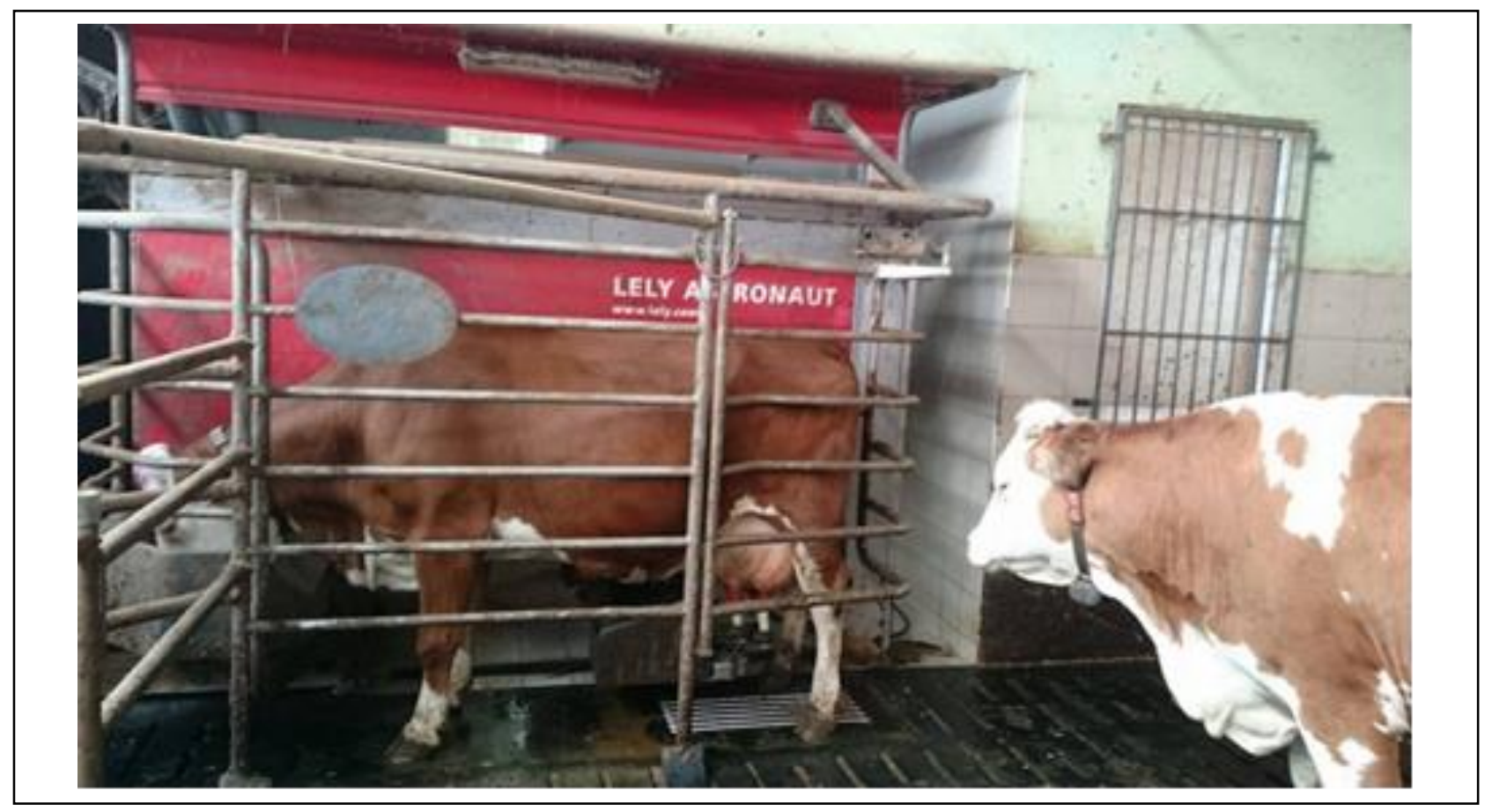

Fig. 2. Lely Astronaut A4 on investigated farm (Vrzel, 2017).

The main feature of the milking robot Lely Astronaut A4 lies in the "I-flow" Cows can enter the milking box from the back and leave it in the front (without turning). In this way, the learning process is shortened, the flow of animals and the work capacity of the milking robot are increased. The milking robot box opens on three sides (Ciupe \& Maniu, 2014).

The Lely Astronaut A4 cleans teats with two brushes that rotate against each other. After cleaning, the entire system is thoroughly disinfected, which prevents contamination. After steam cleaning, a short rinse of milk beakers with clean water is followed. Lely MQC (Milk Quality Control) is located inside the arm of the robot just beside the udder. During milking, the milk is continuously monitored per quarter. The indicators monitored by MQC are: milk colour by udder quarter, fat and protein content of milk, lactose content in milk, electrical conductivity of milk by udder quarter, milk temperature, SCC count by udder quarter, cow activity, weight of cows, the milking of each cow, milking time, milk flow and the amount of feed consumed (Ciupe \& Maniu, 2014).

\subsection{Methodology}

The analysis comprises the data for the period of 8 years (from 2009 to 2016). Data were obtained from the cattle database CPZ Govedo. Data originated from regular AT4 method of milk performance testing (test-day every 4 weeks - alternatively morning/evening) for all cows in the herd and comprised the data on milk yield and composition. 
The data were obtained for three periods, namely:

- the first period - before the introduction of a dairy robot (from January 2009 to November 2013),

- the second period - intermediate period (from December 2013 to May 2014),

- the third period - after the introduction of a dairy robot (from June 2014 to December 2016).

They included average milk yield, fat, protein and lactose contents, and total number of somatic cells count (SCC) in milk on the day of control.

Structure of the herd is presented in Tab. 1.

\begin{tabular}{|l|l|l|l|l|}
\hline Category & $\begin{array}{l}\text { No. of animals } \\
\text { before the } \\
\text { introduction of } \\
\text { AMS }\end{array}$ & $\begin{array}{l}\text { No. of female } \\
\text { animals } \\
\text { before the } \\
\text { introduction } \\
\text { of AMS }\end{array}$ & $\begin{array}{l}\text { No. of } \\
\text { animals } \\
\text { after the } \\
\text { introduction } \\
\text { of AMS }\end{array}$ & $\begin{array}{l}\text { No. of female } \\
\text { animals } \\
\text { after the } \\
\text { introduction of } \\
\text { AMS }\end{array}$ \\
\hline Less than 6 months 23 & 22 & 38 & 35 \\
\hline $\begin{array}{l}\text { From } 6 \text { to } 12 \\
\text { months }\end{array}$ & 17 & 17 & 7 & 7 \\
\hline From 1 to 2 years & 40 & 39 & 27 & 27 \\
\hline Over 2 years & 105 & 105 & 134 & 132 \\
\hline Together & 185 & 183 & 206 & 201 \\
\hline
\end{tabular}

Tab. 1. Herd structure before and after the introduction of AMS

\subsection{Statistical analyses}

Data were processed with the SAS statistical program. The analysis of variance ANOVA was made to compare the parameters (amount of milk, protein, fat and lactose). ANOVA was also made to compare the number of somatic cells in milk; however, since this variable is not normally distributed, the analysis was based on transformed (logarithmic) values.

\section{Results and discussion}

\subsection{Milk yield}

Fig. 3. shows the average daily milk yield on the day of control from the year 2009 to 2016. The minimum milk yield per animal in the observed period was documented in February 2014 - the milk yield was $12.6 \mathrm{~kg}$. The maximum milk yield in the observed period was noted in March 2016 and was $23.8 \mathrm{~kg}$. If we compare the data on an annual basis the average highest milk yield was documnted in $2016(22.9 \pm 0.6 \mathrm{~kg})$, while the lowest in $2014(15.8 \pm 2.2 \mathrm{~kg})$. Data show that the biggest drop in milk yield was during the intermediate period, from December 2013 to May 2014. In this period, the average daily milk yield was $14.8 \pm 1.7 \mathrm{~kg}$. 
Mergedus, A.; Vrzel, M.; Bunevski, G.; Brus, M. \& Janzekovic, M.: Introduction of...

This is a period has been very stressful for milking cows due to moving to a new stable, adaptation to a new living environment, as well as changes in way of feeding system. After this period, the start of using AMS, there was a slow increase in daily milk yield.

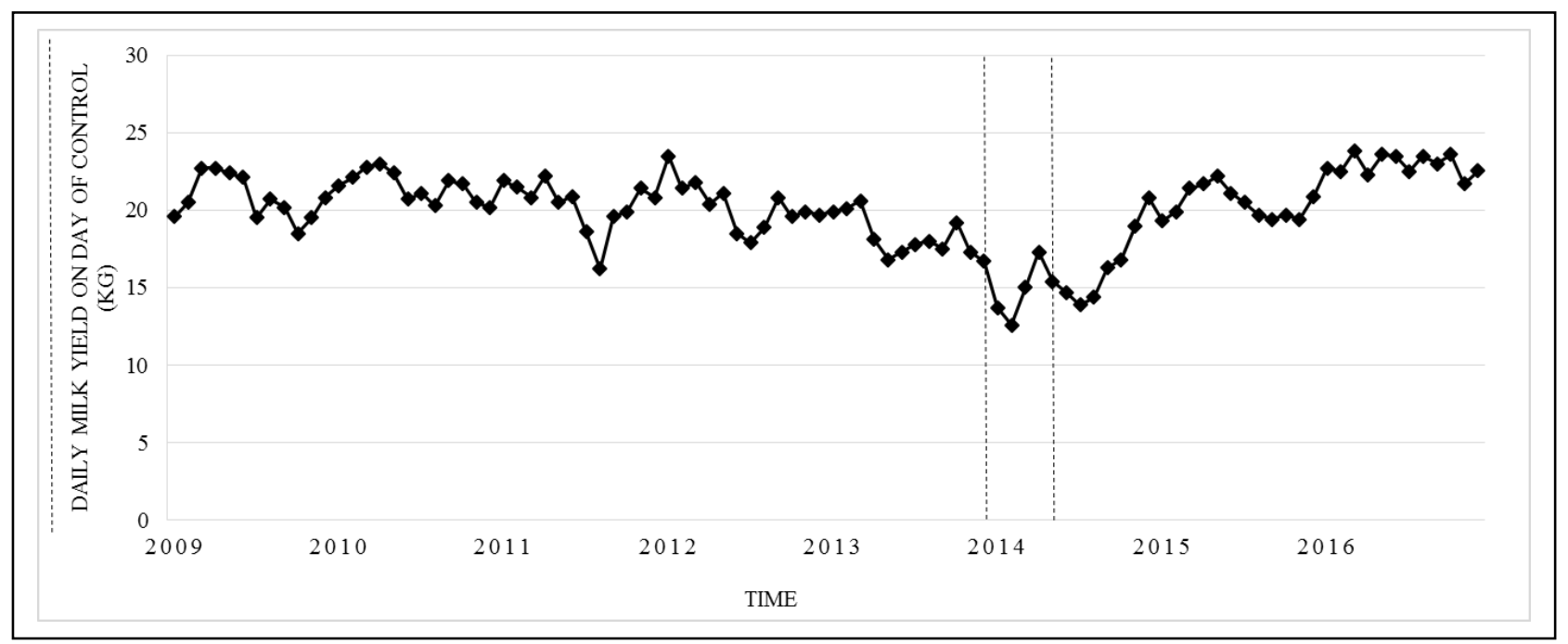

Fig. 3. Daily milk yield per animal from 2009 to 2016.

The fat content on the control day, from 2009 to 2016, is presented in Fig. 4. The total average fat content for the whole studied period was $4.44 \pm 0.2 \%$. The minimum fat content per animal in all observed periods was noted in July $2012(3.8 \%)$, while the maximum was noted in September 2014, namely $5.1 \%$. If we compare the data on an annual basis the highest fat content was $4.75 \pm 0.3 \%$ documented in 2014, while the minimum was documented in 2012 , namely $4.25 \pm 0.3 \%$.

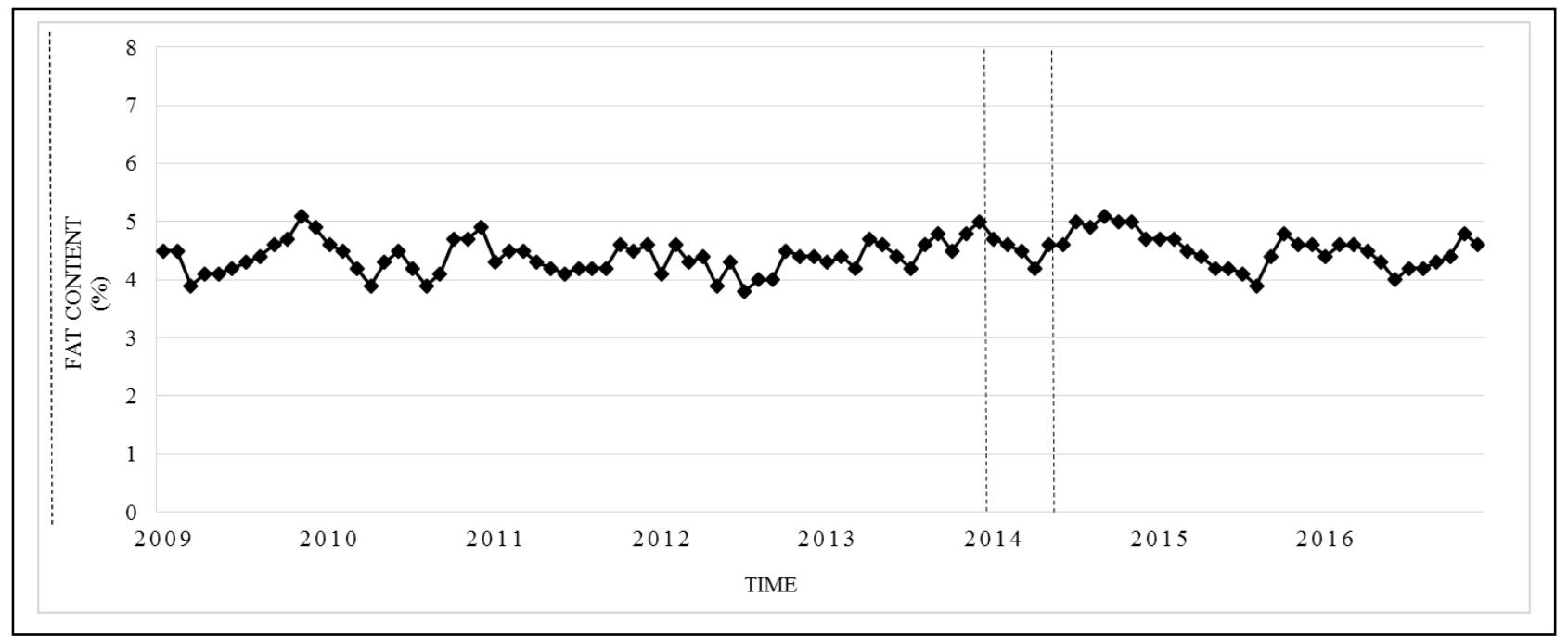

Fig. 4. Fat content on the days of control from 2009 to 2016.

The minimum protein content was detected in 2011, i.e., $3.36 \pm 0.13 \%$ (Fig. 5.). The same low value was also measured in beginning of intermediate period. The highest protein content was detected in 2016 and was $3.57 \pm 0.10 \%$. The minimum protein content per animal in all observed periods was documented in July 2012 and was $3.1 \%$, while the maximum was documented in November 2016, namely $3.55 \%$. 


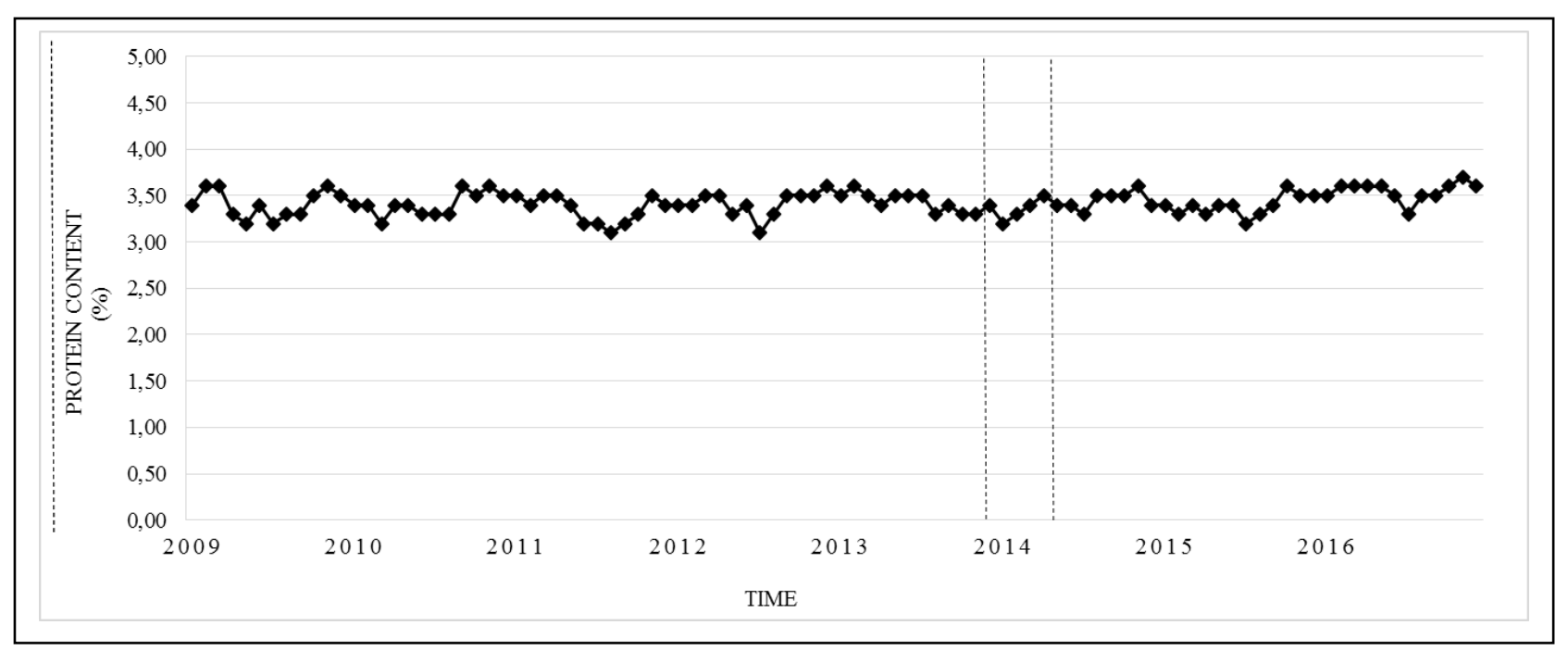

Fig. 5. Protein content on the days of control from 2009 to 2016.

Fig. 6. shows the lactose content on the days of control from 2009 to 2016 . The minimum lactose contents were noted during the period from 2013 to 2014. The minimum content was $4.8 \pm 0.07 \%$.

The highest content was documented in 2011 and was $4.69 \pm 0.07 \%$. During the intermediate period, the average lactose content was $4.58 \pm 0.05 \%$.

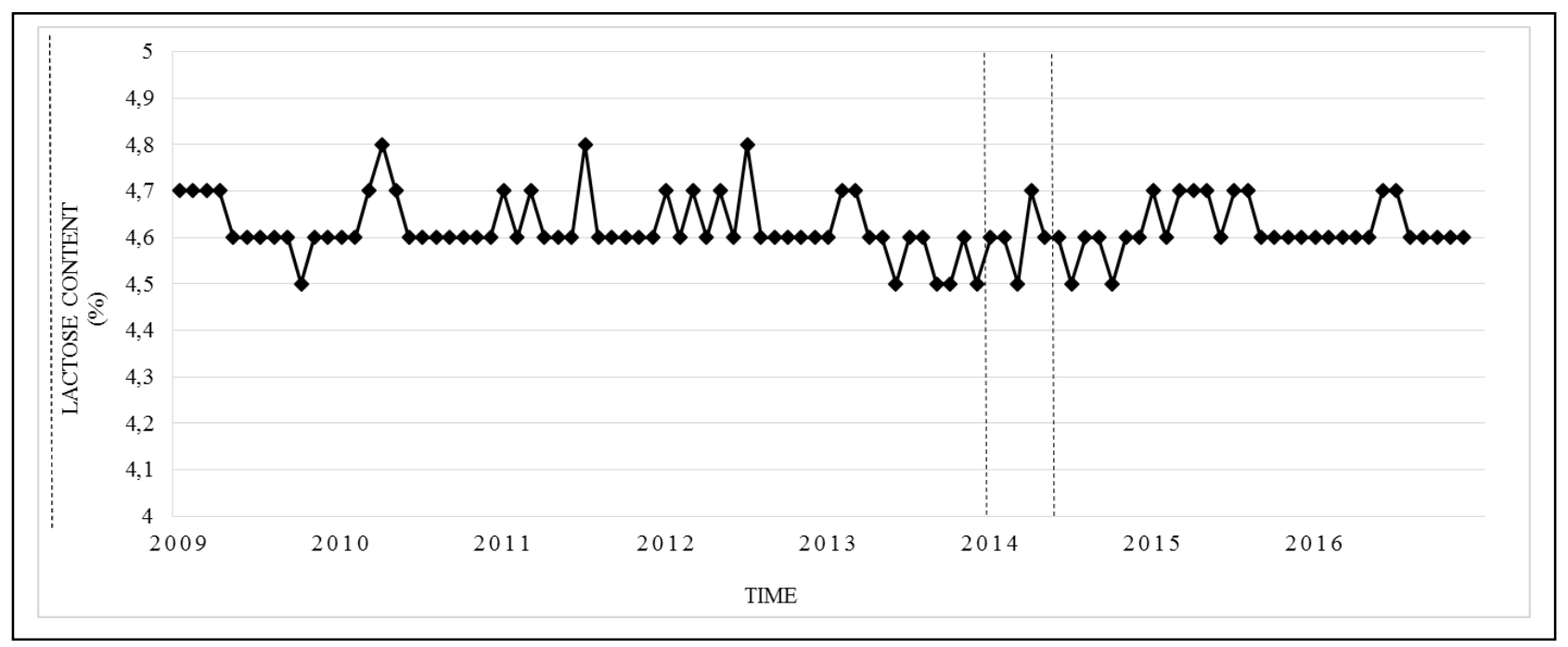

Fig. 6. Lactose content on the days of control from 2009 to 2016.

Fig. 7. shows the total number of somatic cells (SCC) on the days of control during the period from 2009 to 2016. In this graph we can notice a big fluctuation in some years. The highest number of SCC was documented in 2009, namely 419,026, while the lowest in $2012(162,160)$.

The minimum SCC content per animal in all observed periods was measured in November 2015. Total number of SCC was 11,500. The maximum SCC content was in November 2011, namely 721,300. 


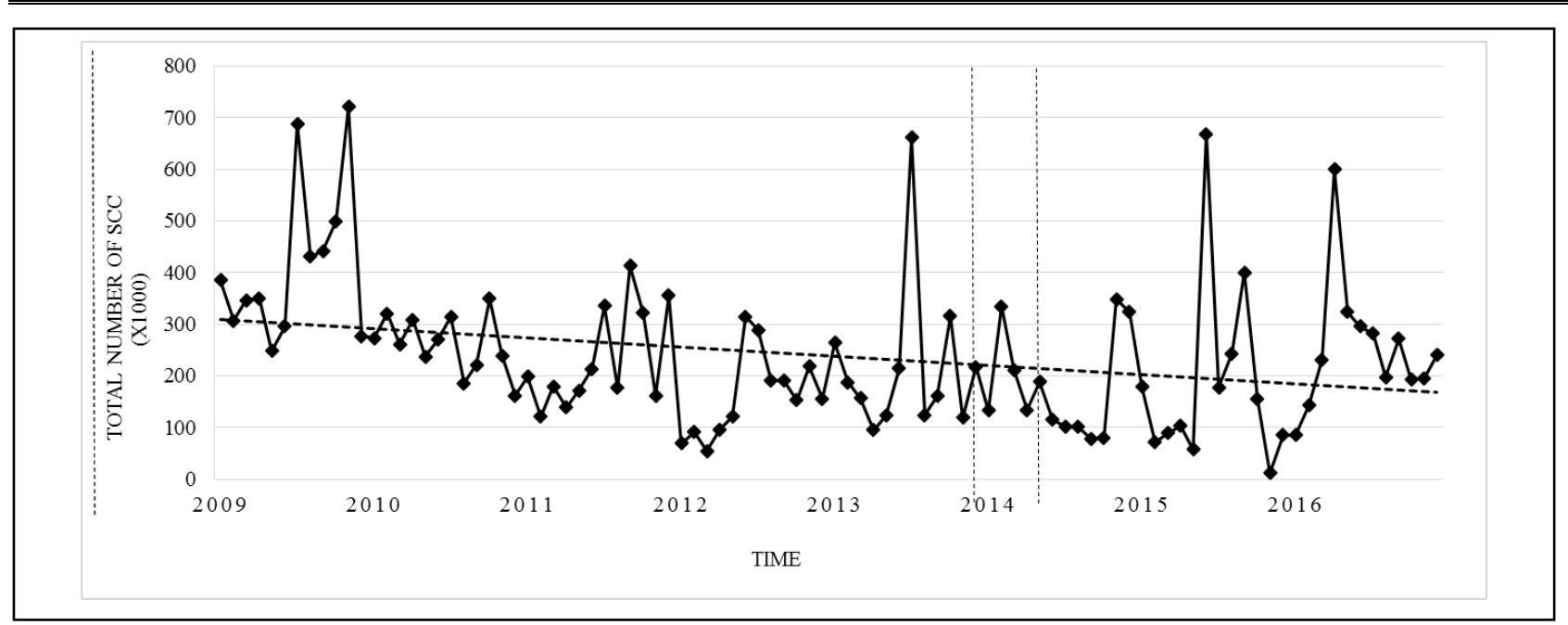

Fig. 7. Total SCC content on the days of control from 2009 to 2016.

The Tab. 2. presents the analysis of ANOVA for milk parameters in two observed periods, before and after introduction of the milking robot. The analysis shows significant differences in all parameters (fat, protein, lactose and SSC), except for the amount of milk. The average daily milk yield in the first period (when using a conventional milking parlor) was $20.4 \pm 1.2 \mathrm{~kg}$ (Tab. 2.). In period after the introduction of AMS, the average daily milk yield was $20.2 \mathrm{~kg}$. With $95 \%$ probability, we can conclude that the fat and protein content increased; so that robotic milking significantly affects these parameters. The fat content in milk rose from 4.37 to $4.53 \%$ ( $\mathrm{p}<0.0001$ ). The protein content increased by a small percentage, from 3.39 to $4.46 \%$, but being significantly higher ( $\mathrm{p}<0.0001)$. The content of lactose was significantly lower after the introduction of milking robot $(\mathrm{p}=0.0024)$ (Tab. 2.). As mentioned earlier, the ANOVA was also used to compare the average numbers of somatic cells between the two periods. Since data for this parameter were not normally distributed, ANOVA was based on transformed logarithmic (ln) values (Tab. 2.). The analysis showed significant differences between the periods before and after the introduction of milking robot $(\mathrm{p}=0.0151)$. The analysis showed a lower number of somatic cells after the introduction of a milking robot.

\begin{tabular}{|l|l|l|l|l|}
\hline Parameter & $\begin{array}{l}\text { Period before the } \\
\text { introduction of AMS }\end{array}$ & $\begin{array}{l}\text { Period after the } \\
\text { introduction of AMS }\end{array}$ & mse & $\begin{array}{l}\text { p } \\
\text { (ANOVA) }\end{array}$ \\
\hline Milk yield (kg) & 20.4 & 20.2 & 6.674 & 0.3044 \\
\hline Fat (\%) & 4.37 & 4.53 & 0.889 & $<0.0001$ \\
\hline Protein (\%) & 3.39 & 3.46 & 0.383 & $<0.0001$ \\
\hline Lactose (\%) & 4.65 & 4.64 & 0.204 & 0.0024 \\
\hline $\begin{array}{l}\text { Number of somatic } \\
\text { cells per ml (ln) } *\end{array}$ & 4.051 & 3.947 & 1.649 & 0.0151 \\
\hline
\end{tabular}

Tab. 2. Milk parameters of milk according to the observed period. (*In - values expressed in a logarithmic form) 
One of the benefits of AMS is increased milk yield from more frequent milking although there were large differences. There are reports that increase in milk yield with AMS ranges from $2 \%$ to $25 \%$ (Tse at al. 2018) which is a relatively wide range. A study which compared milked in a parlor versus an AMS noted that milking frequency under AMS rose to almost 2.5 milking per day. Milk production was slightly higher (2\%) (Wagner-Storch and Palmer, 2003). Milking frequencies of more than twice daily are desired in high milk-yielding cows because it is expected to enhance lactation. However, this assumption is based on results obtained during periods when farms made the transition from 2 to 3 milking per day (Speroni at al., 2006, Svennersten-Sjaunja and Pettersson, 2008). In the study of Speroni et al. (2006) cows in the AMS yielded more milk than cows in the milking parlor $(34.2 \pm 0.7 \mathrm{vs} .29 .4 \pm 0.6 \mathrm{~kg} / \mathrm{d})$, but the study emphasizes that parity and environmental conditions can influence this result. Vorobjovas et al. (2010) reported $18.5 \%(\mathrm{P}<0.05)$ increased milk yield when compared AMS to the conventional milking. The study of Tse at al. (2018) analysed data of 530 farms using AMS. Over $81 \%$ producers reported that milk yield had increased after adopting AMS. Higher production can be attributed to higher milking frequencies in AMS when compared to the conventional milking parlors.

In study of Wirtz at al. (2004), it is noted that in spite of higher milking frequency of 3.0 per day, cows milked in AMS did not reach a higher milk yield when compared to cows milked in parlors 2.0 per day. The study of Rotz et al. (2003) reported that in the cases when the traditional parlor was replaced with an AMS using two single-stall milking units, the milking capacity was marginal for this farm size, providing an average milking frequency of 2.5 per day. Milk production was the same as that of the traditional parlor. These data support our study regarding the level of milk yield, because our milking frequency was similar, approximately 2.5 times a day (data not presented).

Concerning higher protein and fat contents in our study, there are some studies that are opposing our results. Klei et al. (1997) noted lower milk fat and protein contents after using AMS. Similar findings were reported by Klungel et al. (2000), where higher milk fat content $(4.43 \%$ vs $4.37 \%)$ and higher milk protein content (3.49\% vs $3.42 \%$ ) were detected before the introduction of AMS. Wirtz at al. (2004) came to the same conclusion noting that average milk fat content was $0.23 \%$ lower in the milk milked in AMS compared to the milk of the conventionally milked cows. Their study suggested that the reason for this was the variable time interval between two milking actions. No differences, however, were found in the milk protein content.

In contrast, Vorobjovas et al. (2010) compared milk parameters of 90 cows, half in AMS and half in a conventional milking system. Their study reported higher protein level $(0.08 \% ; \mathrm{P}<005)$ and fat content $(0.09 \% ; \mathrm{P}<0.01)$ under AMS, when compared to conventional system. They also analysed the adaption period to AMS and noted increased somatic cell counts, which is similar to our results. Tousova et al. (2014) reported that numerous significant differences were found between the types of milking systems. The milk from the AMS contained significantly higher contents of fat $(+0.16 \%$; $\mathrm{P}<0.01)$, protein $(+0.06 \%$; $\mathrm{P}<0.01)$, casein, and TGC. The study showed that use of the AMS had no negative effect on milk components and quality parameters. 
Mergedus, A.; Vrzel, M.; Bunevski, G.; Brus, M. \& Janzekovic, M.: Introduction of...

In the latest study of Tse at al. (2018), the majority of producers reported no change in milk fat content (56\% of respondents) and milk protein content (79\% of respondents). The main cause of protein decline in milk is poor or insufficient energy supply in the period of intensive milk production during the first three months after calving. With the decline in milk yield and increased feed intake, energy supply is normalized and therefore protein synthesis in rumen is more appropriate (Zgajnar, 1990).

Lactose is a disaccharide consisting of glucose and galactose. The amount in milk is quite constant and does not depend on a diet. It plays an important role as a rudder, as an appetite and as an equalizer of the osmotic pressure of milk (Zgajnar, 1990). Babnik et al. (2004) state that cow's milk in Slovenia contains approximately $4.6 \%$ of lactose. Relatively low fluctuations in the lactose content do not have a greater practical value for detecting disorders. Low lactose content is associated with an increased number of somatic cells in the milk. When the lactose contents is below $4.5 \%$, one has to consider the possibility of mastitis. In our case, the lactose content in milk decreased.

In order to better evaluate the data regarding the number of somatic cells before and after the introduction of milking robot, we conducted a relative frequency analysis (Fig. 8.). The data were divided into five individual classes, namely: $<50,000$ per $\mathrm{ml}$; 50,000 - 100,000 per $\mathrm{ml} ; 100,000$ - 200,000 per ml; 200,000 - 400,000 per $\mathrm{ml}$ and $>$ 400,000 per ml of milk. The columns in Fig 8 indicate relative frequencies associated with the occurrence of somatic cells $(\%)$ in each class for both observed periods. In the first $(<50,000)$ and the second class $(50,000-100,000)$, the percentage is higher for the second observed period. For the third $(100,000-200,000)$, the fourth $(200,000$ $400,000)$ and the highest, fifth class (> 400,000), the percentages are higher for the first observed period. Data suggest that, after the introduction of AMS, a larger share of the measurements with low values is observed. It is also noticeable that before the introduction of a milking robot, there were several measurements with high values of the number of somatic cells in the milk.

When studying literature regarding SCC, we find several contradictions. In early studies associated with the introduction of AMS, an increasing number of SCC was reported in almost all published documents. De Konig (2004) reported that herds under AMS consistently exhibited slightly higher SCC values when compared to conventionally milked herds. The study put the emphasis to the attention of teat cleaning, cleaning of the teat cups and the transfer line to the bulk tank. Rasmussen et al. (2002) noted that studies from several countries documented higher SCC in milk after the implementation of robotic milking due to the increase in new infections. In another study, Friggens et al. (2001) monitored the quality of milk during the periods of one year before and one year after the implementation of AMS. They documented an increase in SCC after the implementation of AMS, particularly in the first three months. 


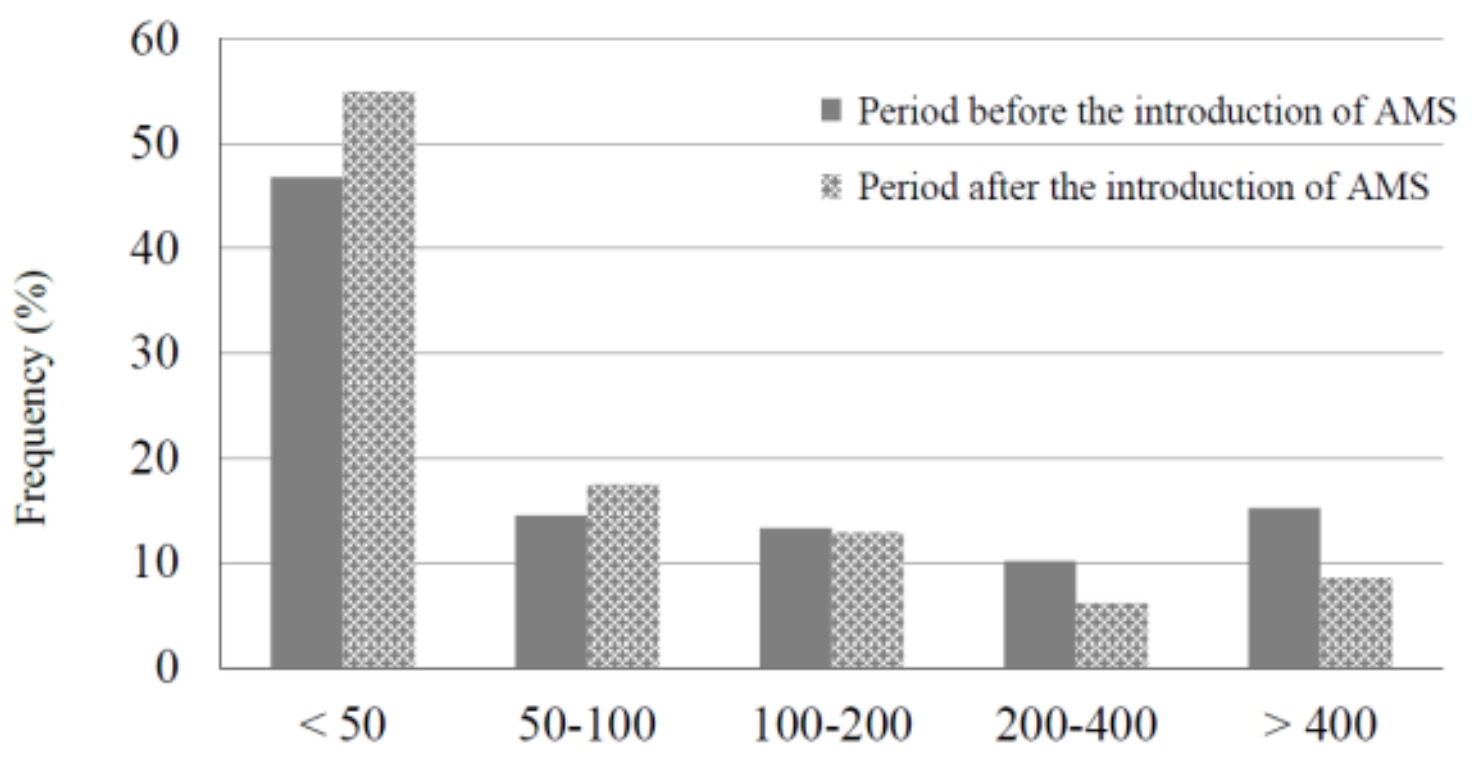

SCC X 1000

Fig. 8. Relative frequency of somatic cell contents in milk before and after introduction of milking robot, given in $\%$.

On the other hand, Tse and al. 2018 noted that SCC decrease was reported by $34 \%$ of farms using AMS, 37\% reported no change and only 20\% reported an increase of SCC. Same was reported by Berglund et al. (2002), Svennersten-Sjaunja and Pettersson (2008) and Tousova at al., (2014).

Berglund et al. 2002, in a 25 week long survey, compared SCC in milk obtained by conventional and automatised system. A significant effect in SCC was observed in quarter strip milk, which was lower in the AMS milked cows. Zecconi et al. 2003 studied quarter milk samples and teat measurements for purposes of detecting intramammary infection frequencies, somatic cell counts, teat thickness changes, teat skin and apex conditions.

The results of this study confirmed that AMS had no negative impact on infection frequencies incidence, SCC and teat tissue conditions when the initial cow health status and overall herd management were good.

If simplified, the introduction of a milking robot positively affects the number of somatic cells. Due to the fact that several factors affect the number of somatic cells in milk (infectious factors, mechanical effects, fever, cold, successive lactation, milk, stress and disease), it is difficult to explain the reasons for the reduction of somatic cells in milk during the introduction of milking robot. Nevertheless, the information is useful when thinking about purchasing AMS. 
Mergedus, A.; Vrzel, M.; Bunevski, G.; Brus, M. \& Janzekovic, M.: Introduction of...

\section{Conclusion}

The dairy industry is constantly introducing new technologies in order to maximize milk yield and profit. The implementation of automatic milking systems appears to be a good solution to achieve this goal. Many opposing data exist about impact of introduction of AMS on production and milk parameters. Our study interest was to evaluate the impact of the change in the farming production system and milking technique. We analyse the data of Slovenian conventional milk producing dairy farm. The analysis comprises the data for the period of 8 years and focus on milk quantity and quality parameters. No significant differences were observed regarding the amount milk production after the introduction of AMS.

The analysis of the data, however, exhibited significant differences in the following parameters: fat, protein, lactose and somatic cell count. The levels of fat, protein and lactose were significantly higher but the number of somatic cells was significantly lower after the introduction of the AMS. This can be due to AMS in association with efficient and regular cleaning of the system and the separation of healthy cows from cows with chronic infectious mastitis. However, we would like to emphasize that animals that did not conform to robotic milking were eliminated from production. In our study AMS had positive effect on several production and quality factors.

The robot had a positive impact on the farmer and his work. The absence of manual milking represents a great physical relief for the farmer and his family. Most research on this topic was done for shorter periods, especially immediately after implementation of AMS and little studies take into consideration longer periods. In future work we need to focus on analysing data for longer periods, which can give better understanding of impact of new technologies on production and quality of farm products.

\section{References}

Babnik, D., Verbic, J., Podgorcek, P., Jeretina, J., Perpar, T., Logar, B., \& Ivanovic, B. (2004). A guide to feeding management of dairy cows with the help of milk control results. Agricultural Institute of Slovenia. ISBN: 961-6224-98-0.

Berglund, I., Pettersson, G., \& Svennersten-Sjaunja, K. (2002). Automatic milking: effects on somatic cell count and teat end-quality. Livestock Production Science, 78(2), 115-124. ISSN: 1871-1413.

Bewley, J. M., Robertson, L. M., \& Eckelkamp, E. A. (2017). A 100-Year Review: Lactating dairy cattle housing management. Journal of dairy science, 100(12), 1041810431. ISSN: 0019-5146.

Calcante, A., Tangorra, F. M., \& Oberti, R. (2016). Analysis of electric energy consumption of automatic milking systems in different configurations and operative conditions. Journal of Dairy Science, 99(5), 4043-4047. ISSN: 0019-5146. 
Ciupe V., Maniu I. (2014). New Trends in Service Robotics. In: Pisla D., Bleuler H., Rodic A., Vaida C., Pisla A. (eds) New Trends in Medical and Service Robots. Mechanisms and Machine Science, vol 16. Springer, ISBN: 978-3-319-01591-0.

De Koning, K., \& Rodenburg, J. (2004). Automatic milking: State of the art in Europe and North America. Automatic milking: A better understanding, Wageningen Academic 27-37. ISBN: 9076998388.

De Koning, K. (2010). Automatic milking-common practice on dairy farms. In: Proceedings of the first North American Conference on Precision Dairy Management and The Second North American Conference on Robotic Milking, pp. 52-67. ISBN: 978-90-76998-38-1. Toronto, March 2-5, 2010. pp. 52-67.

Friggens, N. C., \& Rasmussen, M. D. (2001). Milk quality assessment in automatic milking systems: accounting for the effects of variable intervals between milkings on milk composition. Livestock Production Science, 73(1), 45-54. ISSN: 1871-1413.

Halachmi, I., Metz, J. H. M., Maltz, E., Dijkhuizen, A. A., \& Speelman, L. (2000). Designing the optimal robotic milking barn, part 1: quantifying facility usage. Journal of Agricultural Engineering Research, 76(1), 37-49. ISSN: 0021-8634.

Heikkila, A. M., Vanninen, L., \& Manninen, E. (2010). Economics of small-scale dairy farms having robotic milking. In Proceedings of the First North American Conference on precision dairy management, Toronto, Canada.

Janzekovic, M \& Mergedus, A. (2016). From Conceptual Idea to Construction of New Free Stall for Dairy Cows Using Autodesk Autocad Program, Chapter 04 in DAAAM International Scientific Book 2016, pp.039-048, B. Katalinic (Ed.), Published by DAAAM International, ISBN 978-3-902734-09-9, ISSN 1726-9687, Vienna, Austria. DOI: 10.2507.

Klei, L. R., Lynch, J. M., Barbano, D. M., Oltenacu, P. A., Lednor, A. J., \& Bandler, D. K. (1997). Influence of milking three times a day on milk quality. Journal of Dairy Science, 80(3), 427-436. ISSN: 0019-5146.

Klungel, G. H., Slaghuis, B. A., \& Hogeveen, H. (2000). The effect of the introduction of automatic milking systems on milk quality. Journal of Dairy Science, 83(9), 19982003. ISSN: 0019-5146.

Rasmussen, M. D., Bjerring, M., Justesen, P., \& Jepsen, L. (2002). Milk quality on Danish farms with automatic milking systems. Journal of dairy science, 85(11), 28692878. ISSN: 0019-5146.

Rotz, C. A., Coiner, C. U., \& Soder, K. J. (2003). Automatic milking systems, farm size, and milk production. Journal of Dairy Science, 86(12), 4167-4177. ISSN: 00195146.

Schewe, R. L., \& Stuart, D. (2015). Diversity in agricultural technology adoption: How are automatic milking systems used and to what end? Agriculture and Human Values, 32(2), 199-213. ISSN: 1572-8366.

Speroni, M., Pirlo, G., \& Lolli, S. (2006). Effect of automatic milking systems on milk yield in a hot environment. Journal of dairy science, 89(12), 4687-4693. ISSN: 00195146. 
Mergedus, A.; Vrzel, M.; Bunevski, G.; Brus, M. \& Janzekovic, M.: Introduction of...

Svennersten-Sjaunja, K. M., \& Pettersson, G. (2008). Pros and cons of automatic milking in Europe. Journal of Animal Science, 86(suppl_13), 37-46. ISSN: 0021-8812. Tousova, R., Duchacek, J., Stadnik, L., Ptacek, M., \& Beran, J. (2014). The comparison of milk production and quality in cows from conventional and automatic milking systems. Journal of Central European Agriculture, 15(4), 0-0. ISSN: 1332-9049.

Tse, C., Barkema, H. W., DeVries, T. J., Rushen, J., \& Pajor, E. A. (2018). Impact of automatic milking systems on dairy cattle producers' reports of milking labour management, milk production and milk quality. Animal, 12(12), 2649-2656. ISSN: 1751-7311.

Vorobjovas, G., Zilaitis, V., Banys, A., Juozaitiene, V., \& Jukna, C. (2010). The influence of automatic milking on milk yield and composition in cows. Veterinarija ir Zootechnika, (51), 71-76. ISSN: 1392-2130.

Wagner-Storch, A. M., \& Palmer, R. W. (2003). Feeding behavior, milking behavior, and milk yields of cows milked in a parlor versus an automatic milking system. Journal of Dairy Science, 86(4), 1494-1502. ISSN: 0022-0302.

Wirtz, N., Tholen, E., Spiekers, H., Zahres, W., Pfeffer, E., \& Trappmann, W. (2004). Comparison between automatic and conventional milking concerning milk performance and feed amount. Zuchtungskunde, 76(5), 321-334. ISSN: 0044-540.

Zgajnar J., (1990). Prehrana in krmljenje goved. Ljubljana, Kmecki glas: 216 - 217 pp., 348 p. ISSN: 0350-4093. 